\title{
Chapter 4 \\ Overview of Engineering Mathematics \\ Education for STEM in Georgia
}

\author{
David Natroshvili
}

\subsection{Introduction}

The three-cycle higher education (HE) system has been introduced in Georgia in 2005, when Georgia became a member of the Bologna Process at the Bergen Summit. Bachelor, Master and Doctoral programs have already been introduced in all stately recognised higher education institutions (HEIs), as well as ECTS and Diploma Supplement. All students below doctoral level are enrolled in a twocycle degree system (except for certain specific disciplines such as medicine and dental medicine education)—one cycle education and with its learning outcomes corresponding to the Master's level.

There are three types of higher education institutions; see Table 4.1 and Fig. 4.1.

University - a higher education institution implementing the educational programmes of all three cycles of higher education and scientific research;

Teaching University - a higher education institution implementing a higher education programme/programmes (except for Doctoral programmes). A Teaching University necessarily implements the second cycle-the Master's educational programme/programmes;

College - a higher education institution, implementing only the first cycle academic higher education programmes.

HEIs can be publicly or privately founded, but the quality assurance criteria are the same despite the legal status of the institution.

Bachelor's Programme is a first cycle of higher education, which lasts for 4 years and counts 240 ECTS; after completion of this programme students are awarded the Bachelor's Degree (Diploma).

Master's Programme is a second cycle of higher education, which lasts for 2 years with 120 ECTS; after completion of the program students are awarded the

D. Natroshvili $(\bowtie)$

Georgian Technical University (GTU), Department of Mathematics, Tbilisi, Georgia

(C) The Author(s) 2018

S. Pohjolainen et al. (eds.), Modern Mathematics Education for Engineering

Curricula in Europe, https://doi.org/10.1007/978-3-319-71416-5_4 
Table 4.1 Table of higher education institutions in Georgia

\begin{tabular}{l|c|l|l}
\hline HEI & State & Private & Total \\
\hline University & 12 & 16 & 28 \\
\hline Teaching university & 7 & 24 & 31 \\
\hline College & 1 & 13 & 13 \\
\hline Total & 20 & 53 & 73 \\
\hline
\end{tabular}

\section{EDUCATION SYSTEM IN GEORGIA}

\section{ACADEMIC EDUCATION}

Doctoral Degree
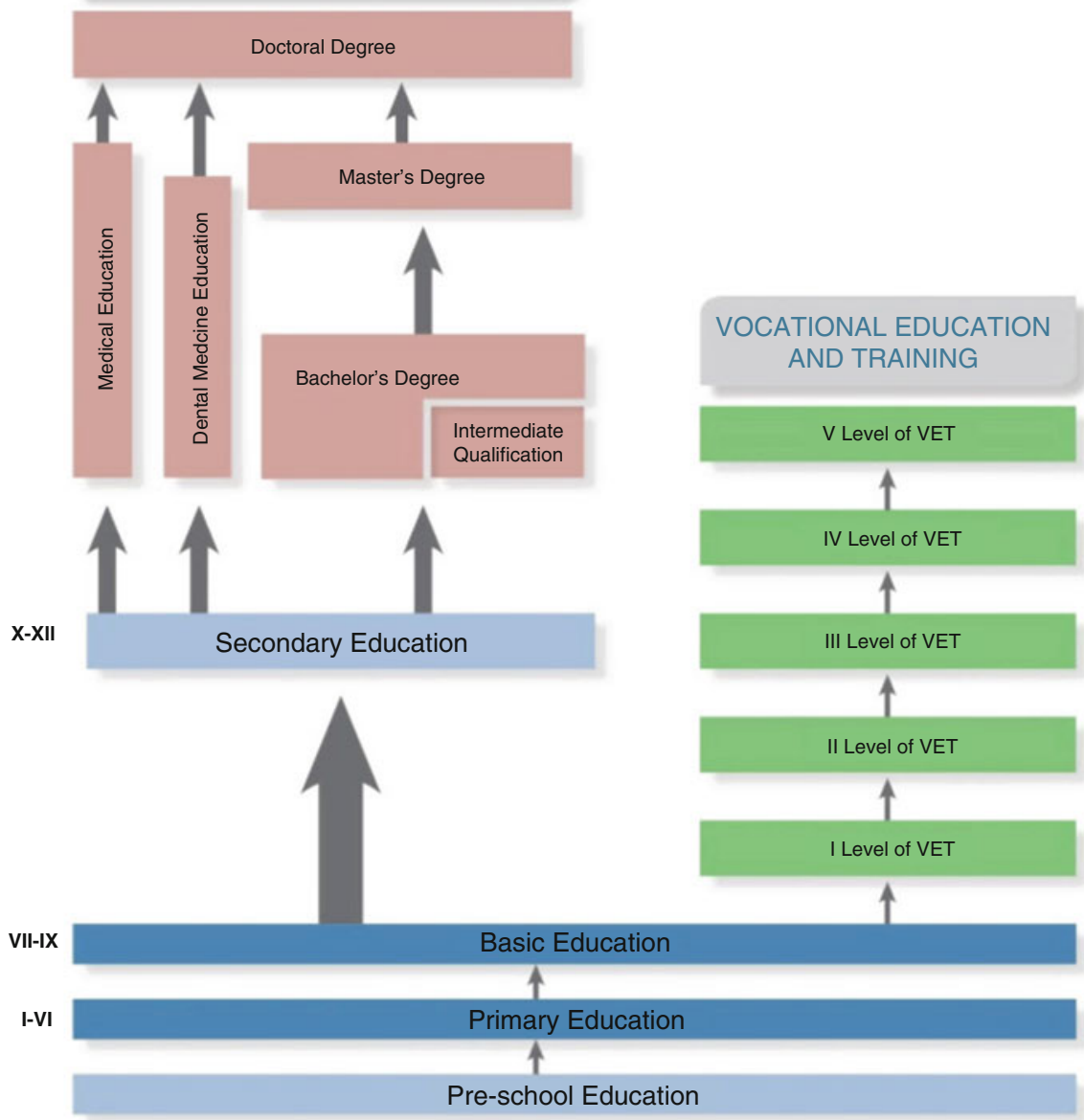

Compulsory Education

Fig. 4.1 The Georgian education system 
Master's Degree (Diploma). Students with Bachelor's Degree Diplomas are required to pass Unified Master's Examinations. The Doctoral Programme is a third cycle of higher education with a minimum duration of 3 years with 180 ECTS; after completion of this programme students are awarded the Doctor's Degree Diplomas. The precondition of entering the third cycle is the completion of the second cycle.

Medical education covers 6 years of studies and counts 360 ECTS.

Dental Medicine education covers 5 years of studies with 300 ECTS.

Medical and dental medicine education is one cycle education and with its learning outcomes corresponds to/equals the Master's level. After completion of these programmes students are awarded diplomas in Medicine and Dental Medicine.

Grading System: There is a unified grading system with the highest 100 score at national level.

Admission-One of the main achievements of the higher education reform in Georgia was the establishment of a system of the Unified National Examinations. The state took a responsibility for students' admission to the first and second cycle of higher education through creating of a centralized, objective system and ensuring the principles of equity and meritocracy.

The Quality Assurance System in Georgia consists of internal and external quality assurance (QA) mechanisms. Internal self-evaluation is carried out by educational institutions commensurate with the procedure of evaluation of their own performance and is summarised in an annual self-evaluation report. The self-evaluation report is the basis for external quality assurance. External QA is implemented through authorization and accreditation. Authorisation is obligatory for all types of educational institutions in order to carry out educational activities and issue an educational document approved by the State. Program Accreditation is a type of external evaluation mechanism, which determines the compatibility of an educational program with the standards. State funding goes only to accredited programmes. Accreditation is mandatory for doctoral programmes and regulated professions as well as for the Georgian language and Liberal Arts. Authorisation and accreditation have to be renewed every 5 years.

The national agency implementing external QA is the Legal Entity of Public Law-National Centre for Educational Quality Enhancement (NCEQE).

\subsection{Georgian Technical University}

As an example of Georgian educational system a more detailed description of the Georgian Technical University (GTU) is given. The GTU is one of the biggest educational and scientific institutions in Georgia.

The main points in the history of GTU include:

1917-the Russian Emperor issued the order according to which was set up the Polytechnic Institute in Tbilisi, the first Higher Educational Institution in the Caucasian region.

1922 - The Polytechnic faculty of Tbilisi State University was founded.

1928 - The Departments of the polytechnic faculty merged into an independent Institute, named the Georgian Polytechnic Institute (GPI). 
In the 1970s - The Institute consisted of 15 full-time and 13 part-time faculties.

1985-1987-For the volume of the advanced scientific research and work carried out by the students, the Polytechnic Institute first found a place in the USSR higher educational institutions. During this period, the Institute became the largest higher educational institution in the Caucasian region as regards the number of students (total 40,000) and academic staff (total 5000).

1990 - The Georgian Polytechnic Institute was granted the university status and named the Georgian Technical University.

1995 - Due to reforms and restructuring of the curriculum, GTU gradually began installation of new training standards introducing Credit System 120 of the UK credits.

2001 - GTU became a full member of the European University AssociationEUA.

2005-GTU joined the Bologna process and introduced 60 ECTS credits.

2005 - Due to the reorganisations conducted at GTU, eight Faculties were set up.

2007-GTU was awarded accreditation by the National Center for Educational Accreditation.

2014 - Due to the reorganisations conducted at GTU, ten Faculties were set up.

Educational programmes at GTU include:

- the Bachelor's Programme-240 ECTS;

- the Master's Programme-120 ECTS;

- the Doctoral Programme-180 ECTS;

- the Vocational Programme-150 ECTS.

There are four languages of study: Georgian, Russian, English and German. GTU has licensed TELL ME MORE language training software, which includes American English, British English, Dutch, French, German, Italian, and Spanish. Learning programmes are also suited to meet user needs, as the software offers Complete Beginner, Intermediate and Advanced levels.

There are ten faculties at GTU:

- the Faculty of Civil Engineering;

- the Faculty of Power Engineering and Telecommunications;

- the Faculty of Mining and Geology;

- the Faculty of Chemical Technology and Metallurgy;

- the Faculty of Architecture, Urban Planning and Design;

- the Faculty of Informatics and Control Systems;

- the Faculty of Transportation and Mechanical Engineering;

- the Business-Engineering Faculty;

- the International Design School;

- the Faculty of Agricultural Sciences and Biosystems Engineering.

Altogether 20,000 undergraduate students study in these faculties. There are also 1251 Master's students, $640 \mathrm{PhD}$ students and 795 students in the Professional stream; see Table 4.2. The total amount of academic personnel at GTU is 1228, with 505 full professors, 533 associate professors, 190 assistant professors, 279 invited professors, 369 teachers and 2176 technical staff. 
Table 4.2 Table of GTU higher education

\begin{tabular}{l|l|l|l|l}
\hline Faculty & $\begin{array}{l}\text { Number of } \\
\text { undergraduate } \\
\text { students }\end{array}$ & $\begin{array}{l}\text { Number of } \\
\text { postgraduate } \\
\text { students }\end{array}$ & $\begin{array}{l}\text { Number of } \\
\text { doctoral } \\
\text { students }\end{array}$ & $\begin{array}{l}\text { Number of } \\
\text { vocational } \\
\text { students }\end{array}$ \\
\hline Civil Engineering & 789 & 90 & 58 & 221 \\
\hline $\begin{array}{l}\text { Power Engineering and } \\
\text { Telecommunications }\end{array}$ & 1448 & 163 & 95 & 120 \\
\hline Mining and Geology & 533 & 32 & 39 & 235 \\
\hline $\begin{array}{l}\text { Chemical Technology } \\
\text { and Metallurgy }\end{array}$ & 850 & 47 & 66 & 140 \\
\hline $\begin{array}{l}\text { Transportation and } \\
\text { Mechanical } \\
\text { Engineering }\end{array}$ & 1493 & 73 & 85 & 716 \\
\hline $\begin{array}{l}\text { Architecture, Urban } \\
\text { Planning and Design }\end{array}$ & 397 & 54 & 42 & 15 \\
\hline Business-Engineering & 4195 & 183 & 48 & 0 \\
\hline $\begin{array}{l}\text { Informatics and } \\
\text { Control Systems }\end{array}$ & 3413 & 267 & 152 & 15 \\
\hline
\end{tabular}

\subsection{STEM Programs at GTU}

The GTU has been offering Engineering Degrees for decades with special attention to the following STEM fields: Computer Sciences, Computer Engineering, Energy and Electrical Engineering, Civil Engineering, Food Industry, and Forestry. The GTU participates in the Millennium Challenge Corporation (MCC) project for STEM Higher Education Development in Georgia. The project objectives are to build up capacity in Georgian public universities and to offer international standard US degrees and/or ABET (Accreditation Board for Engineering and Technology) accreditation in the STEM fields.

Three finalist consortium universities have been selected through an open competition: San Diego State University of California (SDSU); Michigan State University and University of Missouri; North Carolina State University and Auburn University.

The programme is being funded by a \$29 million grant that SDSU was awarded by the MCC that entered into an agreement with the government of Georgia to improve its educational systems and infrastructure.

SDSU was one of 28 universities that competed for funding from the U.S. Millennium Challenge Corporation (MCC) to create a joint higher education programme in Georgia.

Finally, SDSU is approaching this project in partnership with Georgian Technical University, Ilia State University and Tbilisi State University-the three premier public universities in Georgia. Indicative STEM programmes include Electrical (Power) Engineering, Computer Engineering, Computer Science, Chemical Engineering and Civil Engineering fields at Georgian Technical University. 
For this purpose, strengthening ABET-Accredited Georgian Degree Programmes at GTU secures better understanding of educational needs of the next generation of engineers, scientists and educators; achieving ABET accreditation of these programmes is a tangible milestone of quality improvement, providing quality of education and student outcomes of these programmes.

\subsection{Mathematics at GTU}

Mathematics has played and still plays nowadays a fundamental role in engineering education in GTU. In the Georgian Polytechnic Institute the Chair of Mathematics was founded in 1928. Many worldwide well-known Georgian mathematicians had been working and delivering lectures in the Georgian Polytechnic Institute, such as worldwide well-known scientists academicians Niko Muskelishvili, Ilia Vekua, Viktor Kupradze, Boris Khvedelkdze etc.

During the Soviet period all Polytechnic Institutes were forced to follow a unified mathematical curriculum with a sufficiently rich pure theoretical part. It should be mentioned that the level of the school mathematics at that time was very high in the Soviet Union and the entrants were well prepared to start learning of high mathematics, containing a very wide spectrum of courses starting from analytical geometry and classical calculus to boundary value problems for partial differential equations and theory of measure and Lebesgue integrals along with the theory of probability and mathematical statistics.

However, such a high fundamental educational level in mathematics never gave the expected and desired progress in technology and engineering. There was a big gap between theoretical preparation of students and their skills in applied practical aspects. This was one of the main drawbacks of the Soviet educational system.

In 2007, the Department of Mathematics was founded at GTU on the basis of the existing three chairs of high mathematics. The Department of Mathematics belongs to the Faculty of Informatics and Control Systems.

The staff of the Department of Mathematics consists of 20 full-time professors, 21 full-time associate professors, 3 full-time assistant professors, 7 teachers, 16 invited professors, and 5 technical specialists.

From 2008 the BSc, MSc, and PhD accredited programmes in pure and applied mathematics have been launched at the Department of Mathematics (it should be mentioned that presently the mathematical programmes are free of chargefrom 2013 the Georgian Government has covered all expenses for 20 educational programmes; among them is mathematics). 
The Department of Mathematics delivers lectures in high mathematics for all engineering students of GTU. Depending on the specific features of the engineering educational programmes the content of mathematical syllabuses varies and reflects mainly those parts of mathematics which are appropriate for a particular engineering specialisation.

Open Access This chapter is licensed under the terms of the Creative Commons Attribution 4.0 International License (http://creativecommons.org/licenses/by/4.0/), which permits use, sharing, adaptation, distribution and reproduction in any medium or format, as long as you give appropriate credit to the original author(s) and the source, provide a link to the Creative Commons license and indicate if changes were made.

The images or other third party material in this chapter are included in the chapter's Creative Commons license, unless indicated otherwise in a credit line to the material. If material is not included in the chapter's Creative Commons license and your intended use is not permitted by statutory regulation or exceeds the permitted use, you will need to obtain permission directly from the copyright holder. 